\title{
Ecosystem-Based Adaptation for the Impact of Climate Change and Variation in the Water Management Sector of Sri Lanka
}

\author{
Bhabishya Khaniya $\left(\mathbb{D}\right.$, Miyuru B. Gunathilake ${ }^{D}$, and Upaka Rathnayake ${ }^{D}$ \\ Department of Civil Engineering, Faculty of Engineering, Sri Lanka Institute of Information Technology, Malabe, Sri Lanka \\ Correspondence should be addressed to Upaka Rathnayake; upakasanjeewa@gmail.com
}

Received 7 September 2020; Revised 27 October 2020; Accepted 17 February 2021; Published 25 February 2021

Academic Editor: Xander Wang

Copyright (C) 2021 Bhabishya Khaniya et al. This is an open access article distributed under the Creative Commons Attribution License, which permits unrestricted use, distribution, and reproduction in any medium, provided the original work is properly cited.

\begin{abstract}
The climate of Sri Lanka has been fluctuating at an alarming rate during the recent past. These changes are reported to have pronounced impacts on the livelihoods of the people in the country. Water is central to the sustainable functioning of ecosystems and wellbeing of mankind. It is evident that pronounced variations in the climate will negatively impact the availability and the quality of water resources. The ecosystem-based adaptation $(\mathrm{EbA})$ approach has proved to be an effective strategy to address the impact of climate change on water resources in many parts of the world. The key aim of this paper is to elaborate the wide range of benefits received through implementation of EbAs in field level, watershed scale, and urban and coastal environments in the context of Sri Lanka. In addition, this paper discusses the benefits of utilizing EbA solutions over grey infrastructure-based solutions to address the issues related to water management. The wide range of benefits received through implementation of EbAs can be broadly classified into three categories: water supply regulation, water quality regulation, and moderation of extreme events. This paper recommends the utilization of EbAs over grey infrastructure-based solutions in adaptation to climate change in the water management sector for the developing region due its cost effectiveness, ecofriendliness, and multiple benefits received on long-term scales. The findings of this study will unequivocally contribute to filling existing knowledge and research gaps in the context of EbAs to future climate change in Sri Lanka. The suggestions and opinions of this study can be taken into account by decision makers and water resources planning agencies for future planning of actions related to climate change adaptation in Sri Lanka.
\end{abstract}

\section{Introduction}

Climate change/variability and its implementation towards water resources management are two linked concerns for today's world. Climate change/variability can be illustrated as the "change in the state of the climate which can be identified (e.g., using statistical tests) by changes in the mean and/or variability of its properties which persist for an extended period, typically decades or longer [1]. Many researchers believed that the emission of greenhouse gases (GHGs) and changes in the land use are two main reasons for the present alterations in the climate [2]. Sri Lanka, compared to the other countries, gives a lower priority to the GHGs emissions [3].

Climates are to change unpredictably due to the way humans are using environmental resources for concentrated benefits. It is likely to expect increase in the frequency and magnitude of unpredictable precipitation events for some of the regions in the world. However, some other regions are expected to be direr in the future [4]. Developing countries like Sri Lanka are more prone to the vulnerable impacts of climate change, especially facing challenges on natural systems linked meticulously with natural resource management and regulation of biodiversity services [5]. There are many lines of evidence for the climate variations in Sri Lanka $[6,7]$. Impacts of these variations to water resource management, biodiversity conservation, and human health are highly realized in Sri Lankan context as Sri Lanka is recognized as one of the most valuable countries in terms of richness in natural resources together with climatic and topographical variations within a small land territory [8]. This environment is (was and will be) damaged due to the extreme rainfall events and prolonged drought $[9,10]$. It was observed that the mean atmospheric temperature in Sri Lanka 
has been increased by $0.016^{\circ} \mathrm{C}$ per year from 1961 to 1990 . Therefore, the increment is $0.5^{\circ} \mathrm{C}$ for the 30 years. However, globally this happened at a rate of $0.013^{\circ} \mathrm{C}\left(0.39^{\circ} \mathrm{C}\right.$ for the 30 years). Therefore, there is no doubt that Sri Lanka was affected more than most of the other countries by rising atmospheric temperatures $[1,11,12]$. It was further observed that the Sri Lankan annual rainfall was on average decreased by $144 \mathrm{~mm}$ during the years 1961 to 1990 in comparison to the previous 30 years (1931 to 1960) [13, 14]. Sri Lanka has a wide spatial variation of its rainfall and it varies from $900 \mathrm{~mm}$ (dry zones) to $5000 \mathrm{~mm}$ (wet zone). Therefore, the variation in rainfall from one place to another is significantly diversified. Thus, this annual rainfall decrement is calculated based on the average annual rainfall values. Nevertheless, Sri Lanka was ranked second among countries that are mostly affected by extreme climate events in 2017 [15].

It is anticipated that the future climate of the country is also expected to change drastically. Literature gives many predictions according to various climate models on Sri Lanka. However, most of the research was carried out for Special Report on Emissions Scenarios (SRES) by Intergovernmental Panel on Climate Change (IPCC). De Silva [16] predicted that the atmospheric temperature would rise by $1.6^{\circ} \mathrm{C}$ in year 2050 for the $\mathrm{A} 2$ emission scenario and rise by $1.2^{\circ} \mathrm{C}$ for the $\mathrm{B} 2$ scenario. It was predicted that the country's north, northeastern, and northwestern regions would be highly affected by these cases. Importantly, these are in dry zone of the country bounded by the sea. Therefore, the adverse impacts due to the sea water level change are immeasurable [17].

However, the research world has now migrated to Representative Concentration Pathway (RCP) scenarios in climate prediction. These scenarios are based on the greenhouse gas concentration trajectory, which is adopted by the IPCC. However, they are not based on emissions. IPCC 5th assessment report in 2014 showcases four RCP scenarios, RCP2.6, RCP4.5, RCP6, and RCP8.5, for different conditions. These climate scenarios were widely used in the climatic projections and related studies [18], including in Sri Lanka [19-22]. These studies have shown the importance of climate change and its projection for future years.

Not only does the climate change (variation) affect the sea water levels but also it has an effect on many physical phenomena. It is cross-sectoral and, hence, impacts the natural resources, food security, agriculture, energy production, human health, ecosystem, and so forth [23]. Therefore, restoration and expansion of water infrastructure developments are directly impacted by the ongoing climate change and climate variations [4]. In addition, the rapid population growth in most of the developing countries has increased the climate change/variation impacts [24,25]. This is critical in Sri Lanka as it is an island covered by sea. Natcom [26] projected that the sea level rise will reach $1 \mathrm{~m}$ by the year 2070. Therefore, it is clear that, to withstand the adverse impacts of climate variability and climate change in Sri Lanka, immediate actions that are demonstrated by sustainable practices have to be taken. It might not be possible to stop the climate change or climate variation in the world. However, minimization or mitigation is one possible way to overcome the issues of climate change. In addition, adaptation can be considered a better option to get used to the impact of climate change and live with that. If appropriate adaptation actions do not take place at the required time, the risks and damage can be easily amplified [4].

Climate change and water resources management are two linked activities. Therefore, water plays a vital role when it comes to adaptation for climate change [27]. It is reported that $31 \%$ of labour and $12 \%$ of National Gross Domestic Product (GDP) are involved in agriculturerelated activities which are highly sensitive to climate [28]. The future projected decreases in rainfalls and increases in temperature will cause detrimental impacts on agricultural sector, leaving people under increased poverty and hunger.

Climate change in Sri Lanka will threaten both surface and groundwater resources, upon which Sri Lankans highly rely for domestic purposes. The combined impacts of prolonged droughts and sea level rise will amplify the risk of sea water intrusion to coastal aquifers in Sri Lanka and alter tidal series in shoreline areas, which will thereby deplete the availability of freshwater resources [29]. On the contrary, high rainfall levels expected in the wet zones of Sri Lanka will lead to high rates of soil erosion [17]. Baba [3] estimated that the coastal erosion along the shoreline region in Sri Lanka is near $0.35 \mathrm{~m}$ per year. Therefore, not only mitigating the climate change impacts but also adaptation is highly important to the countries like Sri Lanka. The ecosystem-based adaptation (EbA) approach offers solutions to primary water management issues and multitude of auxiliary benefits using a more holistic approach [30]. Ecosystem-based adaptation offers nature-based solutions that are defined as "the forgotten solution," having robust potential to mitigate climate change effects establishing profound ground on implementation of sustainable development goals [31].

Therefore, this paper elaborates the wide range of benefits received through implementation of $\mathrm{EbAs}$ in field level, watershed scale, and urban and coastal environments in the context of Sri Lanka. In addition, the paper discusses the benefits of utilizing EbA solutions over grey infrastructure-based solutions to address the issues related to water management in Sri Lanka, while referring to the literature.

\section{Importance of Ecosystem to the Climate Change Adaptation}

Climate change adaptation is increasingly being adopted as a part of ecosystem-based adaptation, where ecosystem services are conceptualized as a dominant way to reduce climate change impacts [32]. Historically, ecosystem-based adaptation measures were only comprehended as the contrivance to mitigate flooding in the floodplain areas; nevertheless, current practices are oriented towards environmental and social sustainability enhancing human wellbeing by uplifting the livelihood wellbeing of marginalized group of people $[33,34]$. 
Economic concept of demand and supply has been supplementing the close link between ecosystem offered facilities and to management policies regarding conservation of ecosystem properties [35]. These trade-offs need to be monitored for lucrative restoration of biodiversity to maintain adequate supply of ecosystem services [36].

The exploration of the relationship between ecosystembased approaches and climate change adaptation is scrutinized through cost-benefit analysis, while it is also a difficult impractical practice [37]. This section discusses the benefits and services offered by the ecosystems, while emphasizing the importance of ecosystems self-regulating services as the backdrop for adaptation to climate change and eventually to achieve the targeted sustainable development. Ecosystems provide numerous benefits to uplift the economy of a nation provisioning goods and services to meet the local people's day-to-day needs [8].

The services offered by ecosystems are mainly classified into 4 categories: provisioning services, regulating services, cultural services, and supporting services. Safe passage to food, fuel, timber, and other necessities is under the provisioning services category. Climate regulation, regulating water quality and quantity, erosion regulation, and hazard regulation fall under the category of regulation services. Recreational activities and inspirational activities come under the cultural services category, while soil formation and nutrient cycling processes come under the category of supporting services of the ecosystem [38]. Ecosystems were identified as the core elements for addressing the impacts of climate change by the global communities [39]. This can lead to achieving the sustainable development in the ecosystem [40]. In present times, ecosystem-based approach has carried aspirations of ecosystem services model, which is popularly reforming as a value of economic importance while providing biodiversity services [41, 42].

Ecosystem-based adaptation (EbA) is usually cost-effective as it offers consistent financial benefits on the long term relative to the other micromanagement strategies [43]. In addition, the strategies are easily managed according to the ever-changing climate change, even with indigenous level techniques and knowledge [40]. Many international frameworks, including United Nations Framework Convention on Climate Change (UNFCCC) and Sendai Framework for Disaster Risk Reduction (SFDRR), have identified the necessity of EbAs in adapting to and mitigating the climate change risks [44]. At the same time, most of the developing countries have cultivated leading thoughts regarding climate change adaptation, while pledging financial assistance form developed nations [45]. However, it is often debated whether this funding would contribute to successful implementation of ecosystem-based approaches [46]. With growing greenhouse emissions from the developed regions around the world, compensation has to be negotiated, which would help developing countries mobilize the resources to implement adaptation measures to combat detrimental effects of climate change for which they are not directly accountable [47]. It is very challenging to adapt to a particular funding mechanism as novel financial setups of adaptation to climate change require intense political dialogues [48].
Woroniecki [25] highlighted how power relations play an important role in combining social factors to empower ecosystem adaptation strategies to contest climate change, especially in context of developing countries, where political dimension weighs heavy relative to developmental concerns of country citizen. Hence, diverse funding mechanisms suitable for a particular country based on country's national policy, political setup, willingness and commitment of respective governments to carry out adaptation measures, and their past contributions towards adaptation initiatives should be highly prioritized.

\section{Ecosystem-Based Adaptation Measures for Water Management in Sri Lanka}

Sri Lanka is one of the foremost countries to practice ecosystembased adaptation measures (since historical times) to mitigate climate change effects imparting robust techniques for water resource management [48-50]. Contour drains (Figure 1(a)) and contour walls (Figure 1(b)) are two examples to mitigate the landslides and soil erosion in the central hills in Sri Lanka (see Figure 1). The people in Sri Lanka have been using these simple techniques since ancient times. In addition, people used to prefer home gardening over mass-scale farming (Figure 1(c)) in the hill country of Sri Lanka. These are several EbAs quite often practiced in Sri Lanka. These techniques were observed in Serupitiya and Nuwara Eliya area to mitigate the landslides and soil erosion [25].

Besides this, UNDP-led project for ecological tank restoration at Kurunegala district is another adaptation measure featuring ancient water management system of Sri Lanka [53].

In recent times, ecosystem-based adaptation measures have been highly recognized as tools to minimize waterrelated disasters $[54,55]$. The potential EbA approaches, which can be implemented in Sri Lanka to combat the issues driven in water resources management due to the ongoing climate change, are detailed in this section. The relative advantages of EbA-based solutions over grey infrastructure solutions in local scale, watershed level, urban settings, and coastal environments are also reckoned through this section.

\subsection{Ecosystem-Based Adaptation Options in Watershed Areas}

3.1.1. Conservation of Forests in Sri Lanka. Conservation of forests in relation to ecosystem-based adaptation to climate change is rarely discussed in Sri Lankan context $[25,56]$. Local people usually perceive forest just as natural resource to fulfill daily domestic needs which would uplift their household economy [57]. Sri Lanka has lost a significant percentage of forest cover over the last decades due to urbanization and various development activities [58]. These reductions are directly related to swing in climatic factors extreme radiations, prolonged drought, and severe heat [59].

Reforestation and afforestation are two important ways to conserve the forest cover [25]. Reforestation is growing new trees in the areas where there was a recent forest cover, while afforestation is growing new trees in new (fresh) areas. 


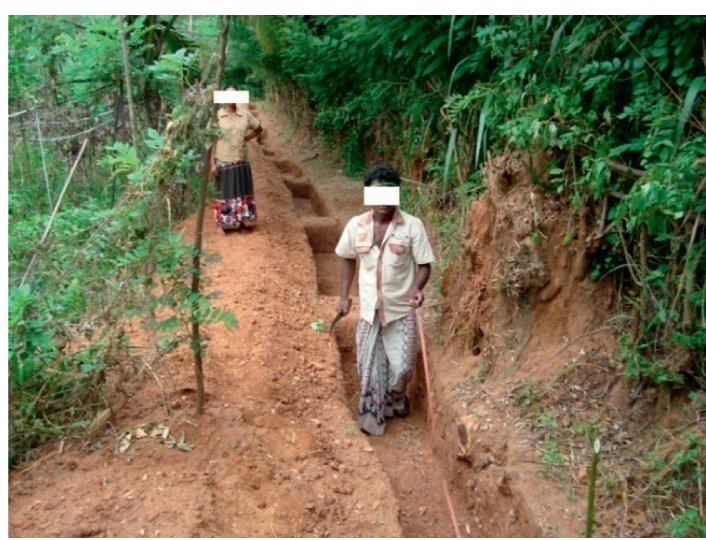

(a)

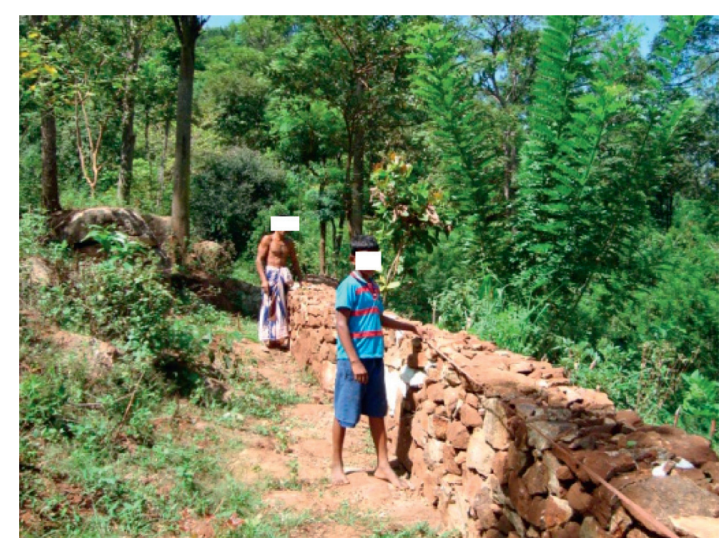

(b)

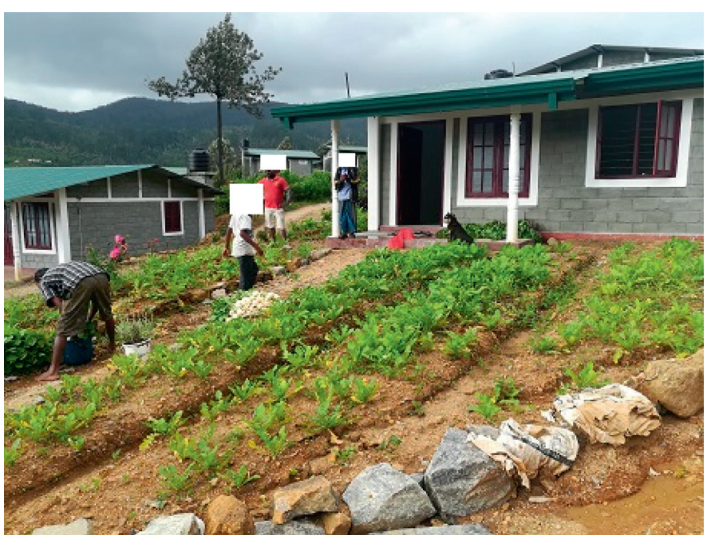

(c)

Figure 1: Ecosystem-based adaptation in central hill, Sri Lanka. (a) Contour drains, Serupitiya [51]. (b) Contour walls, Serupitiya [51]. (c) Home gardening, Dayagama [52].

Forests provide an extensive support to keep the Earth in a balanced ecosystem. Trees that are considered a vital part of ecosystem help to conserve biodiversity, prevent soil erosion, enhance water quality indicators, benefit carbon sequestration, maintain sediment retention capability, offer tourism payback, and offer other diverse facilities for ecosystem regulation [55].

It is a well-known fact that the falling leaves increase the organic content in soil, which thereby increases the waterholding capacity of soils [30]. This is one of the most important natural activities in reducing the downstream floods. The increased interception due to afforestation and infiltration plays a significant role to reduce the magnitude of floods during extreme rainfall events [30].

Sri Lanka has recently implemented a number of projects to enhance its forest cover. Native trees-planting projects carried out in Uyanwatta area Raigama (on 29/11/2013), Atabage area (on 24/01/2015), Kalugala area (on 03/02/2015), Hedigalla area (on 13/06/2015), Akmeemana area (on 14/11/2015), Rakwana area (number of days in 2017-2020), Kathlana area (on 13/01/ 2018), and Illukpathakanda Kalawana area (in 2020) are few examples of short-term projects carried out [60]. In addition, various mass-scale projects are being carried out to increase the forest cover in the Sri Lanka with the help of governmental and nongovernmental organizations. However, for the developing countries like Sri Lanka, integrating sustainability concepts within forest resource management while prioritizing community participation linked within community-based approach would be essential [61]. These attempts will ultimately benefit the country in securing a better world for the future generations. Amendment of existing policies, introduction of new comprehensive policies, and enforcement of coordination among all the parties would address the gaps to set up framework for forest management and should also be essential. On the long term, this jump to institutionalize the adaptation framework would help Sri Lanka not only to prevent disaster reduction but also to regulate benefits that can be reserved from ecosystem services.

3.1.2. Riparian Buffer Strips in Sri Lanka. United States Department of Agriculture's National Resources Conservation Service (USDA-NRCS) defines buffer strips as vegetated or forested areas adjacent to the streams, lakes, or rivers of herbaceous vegetation, which preserve the water quality and aquatic habitats. This vegetation could be trees, shrubs, or a combination of trees or shrubs established at the edge of the watershed along the stream. The flow from the cropland is passed through the buffer strips, while nutrients 
(e.g., nitrogen and phosphorus) and sediments are retained in the buffer strips [62]. Hence, buffer strips replicate the process of conventional water treatment plants [63].

Growing trees along the banks of the rivers is not a new thing to Sri Lanka. Sri Lankans might not know the technical name for the process; however, they have protected the riverbanks by growing various types of trees. This is similar to providing riparian buffer strips. Bamboo tree (Bambusoideae) is one of the most common trees that anyone can see along the rivers to protect soil erosion. In addition, trees like Midella (Barringtonia racemosa), Kumbuk (Terminalia arjuna), and Rambuk (Erianthus arundinaceus) are frequently found along the rivers [64]. These trees not only protect the soil erosion but also protect the nearby settlements by holding flood water during the flood. However, urbanization and other human activities have threatened these trees along the riverbanks. Construction industry has consumed a lot of Bamboo trees. However, a little restoration has been taken to revert back the greenery of the ecosystem.

Nevertheless, use of riparian buffer strips in Sri Lanka is highly valued in terms of agricultural sustainability as a way to protect water resources from pollution for irrigation purposes [65]. Riparian buffer zone development was carried out at Deduru Oya (Oya is one of the local terms for river) basin as bioengineering practice to conserve riverbank [64]. Along with this, the NeoSynthesis Research Centre (NSRC), an organization focused on sustainable agricultural practices and natural landscape restoration, is working to rehabilitate the bank areas of various riverbanks such as Maha Oya, Hulu Ganga (Ganga is another local term for river), Rakwana Ganga, and Mathatilla Oya using riparian buffer strips to prevent contamination of water resources while remediating the spatial landscape heterogeneity with active participation from the community people.

However, use of riparian buffer strips in Sri Lanka is not entrenched with any government rules, neither there are any regulating bodies to promote community engagement to riparian buffer zone development. Therefore, government organizations should urge to develop an adaptable framework for implementation of riparian buffer strips encouraging public level commitment nourishing sociocultural thoughts to familiarize local people with the formulated development policy.

3.1.3. Usage of Natural Wetlands in Sri Lanka. Wetlands offer multiple benefits to the mankind and the environment by providing a wide spectrum of ecosystem supports, while acting as hydrological buffer system [66]. Wetland restoration and conservation have been identified as an improved integrated water management technique, for example, implementation of wetlands as an adaptation tool to sustainable water management at Murray-Darling Basin, Australia, under climate change scenario [35, 67]. Wetlands have common characteristics of terrestrial and aquatic systems and of both lotic and lentic systems [35]. Variety of hydrological, biological, and geochemical processes facilitates the functions of wetlands [68]. Wetlands explicitly support millions of people through water purification (removal of nitrogen and phosphorus), mitigating the severity of floods (attenuation of flood peaks and retention of surface waters), providing aesthetic beauty and recreational areas, providing space for wildlife habitat and biodiversity conservation, providing fertile soil for agricultural production, and providing timber and fuel [69]. Carbon sequestration is another benefit received by wetland, which is an important provision in terms of climate regulation [70]. In addition, coastal wetlands reduce the severity of coastal flooding by acting as a barrier against saline water intrusion [30]. Since wetlands and marshes store excess rainfall during extreme events, additional energy costs for pumping can be minimized. Apart from this, wetlands demonstrate favorable role to handle various activities such as groundwater recharge, erosion resistor, storm protection, and shoreline stabilization [71]. In present times, wetlands ecosystems are likewise treated as key resource to disaster risk reduction due to climate change specifically in urban setting [72].

Wetlands are treated as major value for ecotourism, aesthetic beauty, and recreation in Sri Lanka. Approximately, they cover $15 \%$ of the total land area in Sri Lanka [73]. Colombo, the capital city of the country, along with the coastal regions in Sri Lanka is surrounded by spacious natural wetlands linked with each other; nevertheless, there are ample lines of evidence supporting that these wetlands have undergone several hydrological alterations and their functionality are at prudent risk in perspective of multiple stressors triggered by human attitude to utilize the ecosystem services recklessly [74]. While anticipating wetlands to eliminate climate change risks, it is equally important to preserve the existing wetlands such as freshwater wetlands, lagoons, estuaries, swamp forests, and man-made wetlands which will comfort struggle against climate change [75]. Shifts in ecological regimes due to land encroachment and excessive discharge of wastewater on wetlands causing environmental degradation have put devastating insecurity on future performances of Sri Lankan wetlands. These issues can only be resolved through close monitoring of land use changes by applying modelling techniques to study the changes. There are various initiatives being formulated by Ramsar Convention and United Nations Framework Convention on Climate Change (UNFCCC) under supervision of Government of Sri Lanka to improve resiliency on wetland conservation [23, 76]. This action programme should be in line with cultural setting of the society; theoretical background studies delivered through research and national water resource management policy.

Nevertheless, it is important to exhibit the importance of two wetland systems in the western belt of Sri Lanka. The Muthurajawela marsh and Kolonnawa marsh offer multiple benefits to the living beings in the surrounding areas [77]. The flood waters received during high rainfall seasons from upper reaches are buffered. Then, they are discharged slowly to the Negombo lagoon, hence reducing the negative impacts of flooding on the downstream areas. The lagoon also acts as a source of freshwater delta to moderate salinity and pollution levels. It is estimated that the economic value received through flood attenuation and industrial and 
domestic wastewater purification due to these lagoons is around 500,000 United States Dollars (USD) per year [30]. Therefore, it is highly important to conserve the existing wetlands from the developing activities and then to use them effectively to adapt to the ongoing climate change.

\subsection{Ecosystem-Based Adaptation Options in Coastal Ecosystems}

3.2.1. Mangrove, Coastal Marshes, Dunes, and Barrier Reefs. Mangroves, coastal marshes, dunes, and barrier reefs are regarded as parts of coastal ecosystem. They offer varied functionality analogous to grey infrastructure measures such as dikes, levees, and sea walls in line with associated economical cost [78]. These natural breakwaters result in absorbing the energy of ocean waves, thus reducing the structural damage [79]. The mangrove forests reduce the severity of storm surges protecting upland areas from coastal vulnerability [ 80,81$]$. The role played by mangroves to protect people and properties in recent tsunami was regarded to be magnificent contribution towards the disaster prevention [82, 83]. Nianthi and Shaw [29] reported that coral reefs, which are natural protector of sea erosion, were partially affected due to 2004 Indian Ocean tsunami depicting the role in coastal protection. Nonetheless, the reefs are evidenced to be declining due to mining works [84].

The mangrove forests provide additional income for the people in proximate areas through accelerated fish and shrimp farming as these forests provide home to majority of commercial fish species [30]. It is estimated that the current mangrove cover in Sri Lanka is around $87 \mathrm{~km}^{2}$. Mangrove forests are scattered in the Jaffna peninsula and northwestern, northeastern, and eastern belts of Sri Lanka. Satyanarayana et al. [85] suggested that Jaffna peninsula along with Kaluwanchikudy-Komari is found to be in vulnerable condition due to reduction in mangroves, dunes, and reefs cover while Yala, Puttalam, and Trincomalee remain resilient. Therefore, Sri Lanka as an island and its coastlines are severely vulnerable to the impacts from climate change causing disruptions on water networks [86].

Due to human interactions and lack of conservation policies of mangroves in perspective of climate change, they are successively transforming as narrow strips today. The main causes of depletion of mangrove in Sri Lanka are accounted to land encroachment for agricultural purposes, urban development, and diminution of forest resources [87]. It is recorded that 23 species of mangroves are found in Sri Lanka, and 3 of them are listed in the National Red List of Sri Lanka [88]. Bruguiera cylindrica (L.) Blume (Mal Kadol in local language), Sonneratia alba Sm. (Yak Kirala in local language), and Xylocarpus granatum J. König (Mutti Kadol in local language) are the three types of endangered mangroves in Sri Lanka. Hence, to reinstate the mangroves as climate change shield, quality saplings should be replanted in the tidal areas with collaboration from local authorities and relevant ministries. It is recommended that these measures should be industrialized as microengineering program generating employment to the local people using integrated modality system. These postdevelopment activities should be monitored closely by collective efforts from all the pertinent authorities. Coastal vegetation such as coconut trees, palm trees, and Casuarina plantations is given more attention by the local communities; however, less attention was given to the mangroves. The local community believes that it is the responsibility of the respective councils and the governments. Therefore, the authors suggest that a detailed study should be conducted assessing multicriteria parameters considering the socioecological thoughts, geomorphological characteristics, land-use phenomenon, and scientific understanding of vegetation patterns in conserving the coastal ecosystem.

\subsection{Ecosystem-Based Adaptation Options in Urban Settings.} Ecosystem-based adaptation in urban areas is extremely important due to the rapid urbanization in the world. Rapid urbanization is not controlled or planned in most of the cities. Therefore, this is a critical issue when addressing the impact of climate change. Increased rainfalls and high intensified rainfall due to climate change are two devastating issues for urbanized area as they can bring flash floods. Therefore, adaptation plans play an important role in mitigating the climate change impacts. However, little information is available on using EbAs in urban areas for mitigating the climate change impacts [89].

Sri Lanka has given much attention to introducing EbAs in its capital city, Colombo. This is due to continuous flooding in the city. Even in an event of an average rainfall in Colombo city, a small flood can be observed (at least on roads). Therefore, EbAs were introduced to reduce the surface runoff in particular. Recently renovated parks are examples for these EbAs. These parks were introduced as jogging tracks so that the parks can also be used for the recreational facilities in addition to the EbAs. Bellanwila jogging track, Nawala walking track, and Diyatha Uyana track are few of the recently developed parks. Infiltration is increased from these green parks; thus, it is expected to reduce the peak surface runoff to Colombo city. These facilities were recently implemented in nearby suburbs and excellent outcomes are witnessed.

Green buildings are another attraction to Colombo city. It is not only ecofriendly but also aesthetically attractive. Clear point residence is such high-rise buildings in Rajagiriya in the heart of Colombo. Natural air cooling due to the green cover in 42 floors made the adaptation to the increased atmospheric temperature. In addition, the green energy supply promotes less burden to the environment. Therefore, this is an excellent example for the usage of EbAs in Colombo. However, more of these types of EbAs are required in congested cities like Colombo. Nevertheless, finding enough space is a challenging activity.

\section{Summary and Conclusions}

The advantages in implementation of EbAs in field level, watershed level, and urban and coastal environments in Sri Lanka are discussed through this paper. This research paper discusses the main benefits of utilizing EbA solutions over grey infrastructure solutions to address issues related to water 
management. It is clear that multifunctionality of EbA approach provides a series of cobenefits apart from the primary solutions, when compared to grey infrastructure-based solutions. Mainly, the benefits of EbAs can be classified into water supply regulation, moderation and extreme events, and water quality regulation. Since EbA solutions are cost-effective solutions, they can be incorporated to address issues related to water management in the developing region. Worldwide scientific community has recognized the importance of integrating naturebased solutions for long-term policy planning in the context of climate change, soil and water conservation, and so forth. Increasing awareness on EbAs and associated costs and benefits, capacity building, and knowledge sharing among agencies and financing should be conducted for EbAs. Methods should be developed to monitor and evaluate the progress of these EbA measures in Sri Lanka. Life cycle assessment and effective monitoring of these EbA approaches should be carried out. The benefits and lessons learnt should also be shared with the general public. Integration of $\mathrm{EbA}$ options into the policy development agenda should include assessment of knowledge support, integration of national development, and capacity building. EbA solutions should be addressed after analyzing local hydrology, resources availability, and climatic conditions. It is equally important to understand the capacity of ecosystems. Hence, sustainable utilization of EbAs relies on understanding and respecting the assimilative capacity of ecosystems.

\section{Data Availability}

The review data which authors have used for this review paper are available from the corresponding author upon request.

\section{Conflicts of Interest}

The authors declare that they have no conflicts of interest.

\section{Acknowledgments}

The authors would like to acknowledge the support and motivations provided by Engineers, Anura Panditharathne, Anura Gunathilake, and Pushpika Panditharathne, and Professor Mukand S. Babel to conduct this research. The research was conducted at Faculty of Engineering, Sri Lanka Institute of Information Technology, Sri Lanka.

\section{References}

[1] IPCC, "Climate change 2007," in Synthesis Report. Contribution of Working Groups I, II and III to the Fourth Assessment Report of the Intergovernmental Panel on Climate Change, R. K. Pachauri and A. Reisinger, Eds., p. 104, IPCC, Geneva, Switzerland, 2007.

[2] V. H. Dale, R. A. Efroymson, and K. L. Kline, "The land useclimate change-energy nexus," Landscape Ecology, vol. 26, no. 6, pp. 755-773, 2011.

[3] N. Baba, "Sinking the pearl of the Indian Ocean: climate change in Sri Lanka," Global Majority E-Journal, vol. 1, no. 1, pp. 4-16, 2010.

[4] IPCC, "Climate change," in Synthesis Report. Contribution of Working Groups I, II and III to the Fifth Assessment Report of the Intergovernmental Panel on Climate Change, R. K. Pachauri and L. A. Meyer, Eds., p. 151, IPCC, Geneva, Switzerland, 2014.

[5] P. Lamsal, L. Kumar, K. Atreya, and K. P. Pant, "Vulnerability and impacts of climate change on forest and freshwater wetland ecosystems in Nepal: a review," Ambio, vol. 46, no. 8, pp. 915-930, 2017.

[6] W. A. J. M. De Costa, "Climate change research in Sri Lankaare we investing enough?" Journal of the National Science Foundation of Sri Lanka, vol. 40, no. 4, pp. 281-282, 2012.

[7] P. Kurukulasuriya and M. I. Ajwad, "Application of the ricardian technique to estimate the impact of climate change on smallholder farming in Sri Lanka," Climatic Change, vol. 81, no. 1, pp. 39-59, 2006.

[8] J. Kottawa-Arachchi and M. Wijeratne, "Climate change impacts on biodiversity and ecosystems in Sri Lanka: a review," Nature Conservation Research, vol. 2, no. 3, pp. 2-22, 2017.

[9] I. M. S. P. Jayawardena, D. W. T. T. Darshika, H. M. R. Herath, and C. Herath, "Recent trends in climate extreme indices over Sri Lanka," American Journal of Climate Change, vol. 07, no. 04, pp. 586-599, 2018.

[10] L. Zubair, Z. Yahiya, P. Agalawatte, and R. Lokuhetti, “The El Niño event of 2015/16 in Sri Lanka predictions, preparedness, communication and impacts," in Climate Change Secretariaat, NEELAHARITHA-The Climate Change Magazine of Sri Lanka, pp. 40-46, Ministry of Mahaweli Development and Environment, Battaramulla, Sri Lanka, 2016.

[11] L. Chandrapala, "Long-term trends of rainfall and temperature in Sri Lanka," in Climate Variability and Agriculture, Y. P. Abrol, S. Gadgil, and G. B. Pant, Eds., pp. 153-162, Narosa Publishing House, New Delhi, India, 1996.

[12] T. K. Fernando and L. Chandrapala, "Global warming and rainfall variability-Sri Lankan situation," in Proceedings of the 47th Annual Session of Sri Lanka Association for the Advancement of Science (SLASS), p. 138, Colombo, Sri Lanka, June 1992.

[13] L. Chandrapala, "Calculation of areal precipitation of Sri Lanka on district basis using voronoi tessalation method," in Proceedings of National Symposium on Climate Change, Central Environmental Authority, Colombo, Sri Lanka, March 1996.

[14] H. M. Jayatillake, L. Chandrapala, B. R. S. B. Basnayake, and G. H. P. Dharmaratne, "Water Resources and climate change," in Proceedings of Workshop on Sri Lanka National Water Development Report, N. T. S. Wijesekera, K. A. U. S. Imbulana, and B. N.. Paris, Eds., World Water Assessment Programme (WWAP), Marseille, France, 2005.

[15] D. Eckstein, M. Hutfils, and M. Winges, Global Climate Risk Index 2019, Germanwatch, Bonn, Germany, 2018.

[16] C. S. De Silva, "Impacts of climate change on water resources in Sri Lanka," in Proceedings of the 32nd WEDC International Conference on Sustainable Development of water resources, water supply and environmental sanitation, pp. 502-508, Colombo, Sri Lanka, November 2006.

[17] Ministry of Environment, Strengthening Capacity for Climate Change Adaptation Sector Vulnerability Profile: Agriculture and Fisheries, Climate Change Secretariat Sri Lanka, Battaramulla, Sri Lanka, 2010.

[18] X. Chong-Hai and X. Ying, "The projection of temperature and precipitation over China under RCP scenarios using a CMIP5 multi-model ensemble," Atmospheric And Oceanic Science Letters, vol. 5, no. 6, pp. 527-533, 2012. 
[19] K. Dissanayaka and R. Rajapakse, "Long-term precipitation trends and climate extremes in the Kelani River basin, Sri Lanka, and their impact on streamflow variability under climate change," Paddy And Water Environment, vol. 17, no. 2, pp. 281-289, 2019.

[20] T. Gopalakrishnan and L. Kumar, "Potential impacts of sealevel rise upon the Jaffna Peninsula, Sri Lanka: how climate change can adversely affect the coastal zone," Journal of Coastal Research, vol. 36, no. 5, p. 951, 2020.

[21] S. Jayasinghe and L. Kumar, "Modeling the climate suitability of tea [Camellia sinensis(L.) O. Kuntze] in Sri Lanka in response to current and future climate change scenarios," Agricultural And Forest Meteorology, vol. 272-273, pp. 102$117,2019$.

[22] C. Kariyawasam, L. Kumar, and S. Ratnayake, "Invasive plant species establishment and range dynamics in Sri Lanka under Climate Change," Entropy, vol. 21, no. 6, p. 571, 2019.

[23] S. Woroniecki, C. Wamsler, and E. Boyd, "The promises and pitfalls of ecosystem-based adaptation to climate change as a vehicle for social empowerment," Ecology and Society, vol. 24, no. 2, p. 4, 2019.

[24] N. Huq, A. Bruns, L. Ribbe, and S. Huq, "Mainstreaming ecosystem services based climate change adaptation (eba) in Bangladesh: status, challenges and opportunities," Sustainability, vol. 9, no. 6, p. 926, 2017.

[25] S. Woroniecki, "Enabling environments? examining social cobenefits of ecosystem-based adaptation to climate change in Sri Lanka," Sustainability, vol. 11, no. 3, p. 772, 2019.

[26] Natcom, Democratic Socialist Republic of Sri Lanka, Initial National Communication under the United Nations Framework Convention on Climate Change, State Printing Corporation, Padukka, Sri Lanka, 2000.

[27] WWAP (United Nations World Water Assessment Programme), The United Nations World Water Development Report 2015, UNESCO, Water for a Sustainable World, Paris, France, 2015.

[28] Asian Development Bank, Strengthening Disaster Resilience, Asian Development Bank, Mandaluyong, Philippines, 2019.

[29] R. K. W. G. Nianthi and R. Shaw, "Climate change and its impact on coastal economy of Sri Lanka," in The Global Challenge, R. Krishnamurthy, Ed., Research Publishing, Colombo, Sri Lanka, 2015.

[30] UNEP Green Infrastructure, Guide for Water Management: Ecosystem-Based Management Approaches for Water-Related Infrastructure Projects, UNEP Green Infrastructure, Nairobi, Kenya, 2014.

[31] Nature 4 Climate. 2020, https://nature4climate.org/.

[32] S. Lavorel, M. Colloff, S. Mcintyre et al., "Ecological mechanisms underpinning climate adaptation services," Global Change Biology, vol. 21, no. 1, pp. 12-31, 2012.

[33] M. Acreman and J. Holden, "How wetlands affect floods," Wetlands, vol. 33, no. 5, pp. 773-786, 2013.

[34] J. Mercer, I. Kelman, B. Alfthan, and T. Kurvits, "Ecosystembased adaptation to climate change in Caribbean small island developing states: integrating local and external knowledge," Sustainability, vol. 4, no. 8, pp. 1908-1932, 2012.

[35] M. J. Colloff, S. Lavorel, R. M. Wise, M. Dunlop, I. C. Overton, and K. J. Williams, "Adaptation services of floodplains and wetlands under transformational climate change," Ecological Applications, vol. 26, no. 4, pp. 1003-1017, 2016.

[36] V. Acuña, J. R. Díez, L. Flores, M. Meleason, and A. Elosegi, "Does it make economic sense to restore rivers for their ecosystem services?" Journal of Applied Ecology, vol. 50, no. 4, pp. 988-997, 2013.
[37] W. Lange, S. Sandholz, J. Viezzer, M. Becher, and U. Nehren, "Ecosystem-based approaches for disaster risk reduction and climate change adaptation in Rio de Janeiro state," in Strategies and Tools for a Sustainable Rural Rio de Janeiro, pp. 345-359, Springer, Cham, Switzerland, 2018.

[38] Millennium Ecosystem Assessment, Ecosystems and Human Well-Being: Synthesis, Island Press, Washington, DC, USA, 2005.

[39] S. Gabrielsson and V. Ramasar, "Widows: agents of change in a climate of water uncertainty," Journal of Cleaner Production, vol. 60, pp. 34-42, 2013.

[40] R. Munang, I. Thiaw, K. Alverson, M. Mumba, J. Liu, and M. Rivington, "Climate change and ecosystem-based adaptation: a new pragmatic approach to buffering climate change impacts," Current Opinion in Environmental Sustainability, vol. 5, no. 1, pp. 67-71, 2013.

[41] T. Greiber, "Payment for ecosystem services," in Legal and Institutional Frameworksp. 296, IUCN, Gland, Switzerland, 2009.

[42] S. Liu, R. Costanza, S. Farber, and A. Troy, "Valuing ecosystem services," Annals of the New York Academy of Sciences, vol. 1185, no. 1, pp. 54-78, 2010.

[43] R. Munroe, N. Doswald, D. Roe, H. Reid, A. Giuliani, and I. Castelli, Does EBA Work? A Review of the Evidence on the Effectiveness of Ecosystem-Based Approaches to Adaptation, BirdLife International, UNEP-WCMC, IIED and Cambridge University, Cambridge, UK, 2011.

[44] L. Ruangpan, Z. Vojinovic, S. Di Sabatino et al., "NatureBased Solutions for hydro-meteorological risk reduction: a state-of-the-art review of the research area," Natural Hazards and Earth System Sciences, vol. 20, no. 1, pp. 243-270, 2020.

[45] M. Grasso, "The role of justice in the North-South conflict in climate change: the case of negotiations on the adaptation fund," International Environmental Agreements: Politics, Law and Economics, vol. 11, no. 4, pp. 361-377, 2011.

[46] J. B. Smith, T. Dickinson, J. D. B. Donahue et al., "Development and climate change adaptation funding: coordination and integration," Climate Policy, vol. 11, no. 3, pp. 987-1000, 2011.

[47] M. Grasso, Justice in Funding Adaptation under the International Climate Change Regime, Springer Netherlands, Dordrecht, Netherlands, 2010.

[48] R. Vignola, B. Locatelli, C. Martinez, and P. Imbach, "Ecosystem-based adaptation to climate change: what role for policy-makers, society and scientists?" Mitigation and Adaptation Strategies for Global Change, vol. 14, no. 8, pp. 691-696, 2009.

[49] K. Balooni, M. Inoue, T. K. Nath, and M. De Zoysa, How Social Is Socially Oriented Forest Tenure and Land Use Change in Bangladesh and Sri Lanka? Asia Research Institute Working Paper Series, Asia Research Institute, Singapore, 2001.

[50] I. Landström, "Towards collaborative coastal management in Sri Lanka? a study of special area management planning in Sri Lanka's coastal region," Geografiskaregionstudier, vol. 70, p. 185, 2006.

[51] CCCV, "Coping with climate change and variability: lessons from Sri Lankan communities," in Proceedings of the National Workshop on Community Based Adaptation Colombo, Sri Lanka; UNDP Global Environment Facility/Small Grants Programme (UNDP, GEF/SGP), pp. 1-96, Colombo, Sri Lanka, July 2016.

[52] UN-Habitat, Sri Lanka. 2020, Families at the centre https:// unhabitat.lk/photo-gallery/indian-housing-project-in-centraland-uva-provinces-gallery/families-at-the-centre/. 
[53] C. Panabokke, The Small Tank Cascade Systems of the Rajarata: Their Settings, Distribution Patterns and Hydrography, Mahaweli Authority of Sri Lanka, Colombo, Sri Lanka, 2000.

[54] F. G. Renaud, U. Nehren, K. Sudmeier-Rieux, and M. Estrella, "Developments and opportunities for ecosystem-based disaster risk reduction and climate change adaptation," Ecosystem-Based Disaster Risk Reduction and Adaptation in Practice, vol. 42, pp. 1-20, 2016.

[55] N. Uy and R. Shaw, "The role of ecosystems in climate change adaptation and disaster risk reduction," Ecosystem-Based Adaptation, vol. 12, pp. 41-59, 2012.

[56] Sri Lanka UN-REDD Programme, Sri Lanka'S Forest Reference Level Submission to the UNFCCC, UN-REDD, Colombo, Sri Lanka, 2017.

[57] J. Blockhus, A. Wickramasinghe, M. Nurse, and M. Pérez, "Non-timber forest products and local livelihoods in Ritigala, Sri Lanka," International Union for Conservation of Nature and Natural Resources Asia, Gland, Switzerland, 2002.

[58] C. S. Reddy, G. Manaswini, C. S. Jha, P. G. Diwakar, and V. K. Dadhwal, "Development of national database on longterm deforestation in Sri Lanka," Journal of Indian Society of Remote Sensing, vol. 45, no. 5, pp. 825-836, 2017.

[59] G. W. A. R. Dahdouh-Guebas, "Causes of forest dieback in montane forests in Sri Lanka," Economic Review, vol. 34, pp. 38-40, 2008.

[60] Rainforest Protectors of Sri Lanka Projects, "Rainforest protectors of Sri Lanka," 2020, http://www. rainforestprotectors.org/rainforest/Projects.aspx.

[61] Nature Uganda, Ecosystem-based Approaches to Climate Change Adaptation, Local Guidance, NatureUganda, Kampala, Uganda, 2015.

[62] T. Ramilan, F. Scrimgoeur, and D. Marsh, "Modelling riparian buffers for water quality enhancement in the Karapiro catchment," in Proceedings of the 54th Australian Agricultural and Resource Economics Society 2010 Conference, Adelaide, Australia, February 2010.

[63] K. D. M. S. S. Sarathchandra, N. D. K. Dayawansa, and M. I. M. Mowjood, "Situation analysis of socio environmental aspects of non point source water pollution in intensively cultivated areas of Nuwara Eliya," Tropical Agricultural Research, vol. 28, no. 4, pp. 425-434, 2017.

[64] M. Soyza, M. Ranagalage, and L. Manawadu, "Model for river bank conservation and proper land use planning," in Proceedings of the International Forestry and Environment Symposium 2013 of the Department of Forestry and Environmental Science, University of Sri Jayewardenepura, Jayewardenepura, Sri Lanka, July 2013.

[65] H. P. Henegama, N. D. K. Dayawansa, and S. D. Silva, "An assessment of social and environmental implications of agricultural water pollution in Nuwara Eliya," Tropical Agricultural Research, vol. 24, no. 4, pp. 304-316, 2015.

[66] D. C. Donato, J. B. Kauffman, D. Murdiyarso, S. Kurnianto, M. Stidham, and M. Kanninen, "Mangroves among the most carbon-rich forests in the tropics," Nature Geoscience, vol. 4, no. 5, pp. 293-297, 2011.

[67] M. C. Acreman and G. E. Hollis, Water Management and Wetlands in Sub-saharan Africa, IUCN, Gland, Switzerland, 1996.

[68] BA. Middleton and N. Souter, "Functional integrity of wetlands, hydrologic alteration and freshwater availability," Ecosystem Health and Sustainability, vol. 2, no. 1, Article ID e01200, 2016.
[69] Y. Liu, W. Yang, L. Leon et al., "Hydrologic modeling and evaluation of best management practice scenarios for the grand river watershed in southern Ontario," Journal of Great Lakes Research, vol. 42, no. 6, pp. 1289-1301, 2016.

[70] W. R. Moomaw, G. L. Chmura, G. T. Davies et al., "Wetlands in a changing climate: science, policy and management," Wetlands, vol. 38, no. 2, pp. 183-205, 2018.

[71] U. Sarkar, S. Nag, M. Das, G. Karnatak, and D. Sudheesan, Conserving Wetlands-An Effective Climate Change Adaptation in India, ICAR- Central Inland Fisheries Research Institute, Kolkata, India, 2016.

[72] M. Hettiarachchi, K. Athukorale, S. Wijekoon, and A. de Alwis, "Urban wetlands and disaster resilience of Colombo, Sri Lanka," International Journal of Disaster Resilience in the Built Environment, vol. 5, no. 1, pp. 79-89, 2014.

[73] J. D. S. Dela, Fourth Country Report from Sri Lanka to the United Nations Convention on Biological Diversity, Ministry of Education, Battaramulla,Sri Lanka, 2009.

[74] CEA, Wetland Site Report and Conservation Management Plan-Colombo Flood Detention Areas, Central Environmental Authority of Sri Lanka, Colombo, Sri Lanka, 1994.

[75] F. Dahdouh-Guebas and J. L. Pulukkuttige, "A bibliometrical review on pre- and posttsunami assumptions and facts about mangroves and other coastal vegetation as protective buffers," Ruhuna Journal of Science, vol. 4, pp. 28-50, 2009.

[76] G. Bergkamp and B. Orlando, "Wetlands and climate change," in Exploring Collaboration between the Convention on Wetlands and the United Nations Framework Convention on Climate ChangeBackground paper from the World Conservation Union (IUCN), Gland, Switzerland, 1999.

[77] L. Emerton and E. Bos, Counting Ecosystems as an Economic Part of Water Infrastructure, IUCN, Cambridge, UK, 2004.

[78] A. S. Ratnayake, Y. Sampei, N. P. Ratnayake, and B. P. Roser, "Middle to late Holocene environmental changes in the depositional system of the tropical brackish Bolgoda Lake, coastal southwest Sri Lanka," Palaeogeography, Palaeoclimatology, Palaeoecology, vol. 465, pp. 122-137, 2017.

[79] M. E. Hanley, S. P. G. Hoggart, D. J. Simmonds et al., "Shifting sands? coastal protection by sand banks, beaches and dunes," Coastal Engineering, vol. 87, pp. 136-146, 2014.

[80] B. Chatenoux and P. Peduzzi, "Impacts from the 2004 Indian Ocean Tsunami: analysing the potential protecting role of environmental features," Natural Hazards, vol. 40, no. 2, pp. 289-304, 2007.

[81] A. Colls, N. Ash, and N. Ikkala, Ecosystem-Based Adaptation: A Natural Response to Climate Change, IUCN, Gland, Switzerland, 2009.

[82] S. Sandilyan and K. Kathiresan, "Mangroves as bioshield: an undisputable fact," Ocean \& Coastal Management, vol. 103, pp. 94-96, 2015.

[83] H. Yanagisawa, S. Koshimura, K. Goto et al., "The reduction effects of mangrove forest on a Tsunami based on field surveys at Pakarang Cape, Thailand and numerical analysis," Estuarine, Coastal and Shelf Science, vol. 81, no. 1, pp. 27-37, 2009.

[84] The World Bank and the United Nations, Natural Hazards, Unnatural Disasters: The Economics of Effective Prevention, The World Bank, Washington, DC, USA, 2010.

[85] B. Satyanarayana, T. Van der Stocken, G. Rans et al., "Islandwide coastal vulnerability assessment of Sri Lanka reveals that sand dunes, planted trees and natural vegetation may play a role as potential barriers against ocean surges," Global Ecology and Conservation, vol. 12, pp. 144-157, 2017. 
[86] R. A. Feagin, N. Mukherjee, K. Shanker et al., "Shelter from the storm? use and misuse of coastal vegetation bioshields for managing natural disasters," Conservation Letters, vol. 3, no. 1, pp. 1-11, 2010.

[87] B. Satyanarayana, N. Koedam, K. De Smet et al., "Long-term mangrove forest development in Sri Lanka: early predictions evaluated against outcomes using VHR remote sensing and VHR ground-truth data," Marine Ecology Progress Series, vol. 443, pp. 51-63, 2011.

[88] A. R. Gunawardena, S. P. Nissanka, N. D. K. Dayawansa, and T. T. Fernando, "Above ground biomass estimation of mangroves located in Negombo-Muthurajawela wetland in Sri Lanka using ALOS PALSAR images," Tropical Agricultural Research, vol. 27, no. 2, pp. 137-146, 2016.

[89] D. Geneletti and L. Zardo, "Ecosystem-based adaptation in cities: an analysis of European urban climate adaptation plans," Land Use Policy, vol. 50, pp. 38-47, 2016. 